\title{
Laboratory diagnosis of peritonitis in patients undergoing continuous ambulatory peritoneal dialysis
}

\author{
PATRICIA FENTON \\ From the Department of Bacteriology, Royal Hallamshire Hospital, Sheffield, S10 2SF
}

SUMMARY A simple laboratory method for culture of continuous ambulatory peritoneal dialysis (CAPD) fluids is described. Guidelines for antimicrobial therapy are discussed based on results from 18 patients studied over an 11-week period. Cephalosporins appeared to be a rational choice for therapy while awaiting laboratory results.

Continuous ambulatory peritoneal dialysis (CAPD) has recently been introduced as an alternative to haemodialysis or peritioneal dialysis for patients suffering from chronic renal failure. The advantages of this procedure include the lack of need for special equipment in the home, the fact that bag changes can be carried out by the patient without assistance, the lack of need for vascular access, the increased mobility resulting from independence of a dialysis centre and an increased feeling of wellbeing. '

However it has been found that a significant proportion of patients receiving this form of dialysis develop symptoms and signs suggestive of bacterial peritonitis. ${ }^{2}$ Conventional methods of culture of peritoneal dialysate from these patients have often proved negative despite the presence of pus cells in the peritoneal fluid and clinical evidence of infection. ${ }^{3}$ In theory there are three possible explanations for negative culture results. Firstly the condition may be non-bacterial in origin. Alternatively even if the infection is bacterial the causative agents may not be detected by the methods used because their numbers are small or because their cultural requirements are exacting. The third possibility is that bacteria may be prevented from growing in vitro by substances present in the dialysate.

Various workers have attempted to improve the rate of recovery of bacteria. ${ }^{2-4}$ In one method $100 \mathrm{ml}$ of dialysate is passed through a $0.45 \mu \mathrm{m}$ membrane filter-the filter is divided and half cultured aerobically, the other half anaerobically on enriched solid media. The disadvantages of methods involving filtration of large volumes of fluid include blockage of the filter with cells and contamination of filters during division and transfer to solid media. Another method involves inoculation of $2 \mathrm{ml}$ of dialysate into nutrient broth and. chopped meat carbohydrate broth.

Accepted for publication 17 March 1982
Such broth cultures rely on visual interpretation of turbidity and there is a delay in identification of organisms while awaiting results of subcultures. The risk of contamination occurring when repeated subcultures are performed is another disadvantage.

The aims of this present study were twofold: firstly to evaluate simple methods designed to give the maximum recovery of bacterial pathogens, and secondly to assess which factors might give an early indication of bacterial infection so that appropriate presumptive therapy might be instituted pending the receipt of culture results.

\section{Material and methods}

\section{PATIENTS}

Fifty-nine specimens of dialysis fluid from 18 patients were examined over a period of $11 \mathrm{wk}$. Seven of these patients commenced CAPD during the period of study and the remaining 11 were already established on the programme. Some specimens were obtained from symptom-free patients at routine tube change, others from patients during the course of an episode of peritonitis, and a third group from patients complaining of symptoms other than those of peritonitis.

Peritonitis was diagnosed clinically when the patient presented with abdominal pain or fever with turbid dialysate. "Symptoms other than peritonitis" were defined as those directly related to dialysis but not involving fever and abdominal pain-for example, leakage around the Tenkhoff catheter or catheter blockage.

Samples of fluid were withdrawn with sterile precautions from the injection site of the plastic dialysis fluid bag after disconnection from the patient. Approximately $40 \mathrm{ml}$ of fluid was withdrawn through a needle into a sterile syringe, the needle covered and removed then the fluid injected into two sterile universal containers, thus providing two $20 \mathrm{ml}$ 
samples for laboratory testing. All specimens were taken by trained nursing staff.

All patients who were suspected of having infection received antibiotics empirically. A cephalosporin was added to bags of dialysis fluid before installation and patients were given an oral cephalosporin at the same time. Therapy was subsequently changed if indicated by results of dialysate culture or if the patient failed to respond within $48 \mathrm{~h}$.

\section{LABORATORY METHODS}

The following methods were used on all specimens irrespective of the patient's clinical state. One $\mathrm{ml}$ of dialysate was mixed with $10 \mathrm{ml}$ of molten nutrient agar at $56^{\circ} \mathrm{C}$ and poured into a sterile Petri dish, allowed to set at room temperature and then incubated for a total of $72 \mathrm{~h}$ at $37^{\circ} \mathrm{C}$ in air plus $10 \% \mathrm{CO}_{2}$. A count of red and white blood cells was performed on the dialysate specimen in a FuchsRosenthal counting chamber. A $20 \mathrm{ml}$ aliquot of dialysate was then centrifuged at $3000 \mathrm{rpm}$ for $5 \mathrm{~min}$. Films made from the deposit were stained by Gram's and Leishman's methods. A standard wire loop was used to inoculate $0.01 \mathrm{ml}$ of centrifuged deposit on each of the following media; blood agar (incubated aerobically for $72 \mathrm{~h}$ ), blood agar (incubated anaerobically for $72 \mathrm{~h}$ ) and MacConkey agar (also incubated for a total of $72 \mathrm{~h}$ ). Cultures were read at 24,48 and $72 \mathrm{~h}$.

Fifteen of the 59 specimens were subjected to gas liquid chromatography in an attempt to provide rapid evidence of anaerobic infection. Dialysate $(10 \mathrm{ml})$ was extracted with ether $(1 \mathrm{ml})$ and the extract was subjected to gas liquid chromatography on a Pye Unicam 204 Gas Liquid Chromatograph. A search was made on the print-out for peaks representing volatile fatty acids.

Staphylococci isolated from dialysate fluids were tested for coagulase and DNA'se production. Those giving negative results in these tests were subjected to biochemical investigation by "Staph API" (manufactured by API Système SA France). The seven digit profile number derived from the results was recorded, and compared with that given by any subsequent isolations from the same patient. Enterobacteriaceae were identified by the API $20 \mathrm{E}$ method and other bacteria were identified by standard laboratory methods. Sensitivity testing was carried out by a disc diffusion method on plates incubated at $37^{\circ} \mathrm{C}$, inhibition zones being measured after overnight incubation and compared with those produced on known sensitive control organisms.

\section{Results}

The association between clinical features, cell counts and results of culture is shown in Table 1. Fourteen specimens were received from patients at initial presentation with peritonitis. Of these 11 (79\%) yielded a bacterial growth on culture. A positive result was obtained on subsequent specimen from one of the patients whose original specimen yielded no growth. Both the remaining patients with peritonitis responded to intraperitoneal cefuroxime with oral cephalexin. Table 1 shows that cell counts greater than $500 \times 10^{6} / 1$ were found in 14 of 22 $(63.6 \%)$ of culture-positive fluids but only in nine of $37(24 \cdot 5 \%)$ of culture-negative fluids. Results of cell counts could be available to the requesting clinician within $5 \mathrm{~min}$ of receipt of specimens. It is apparent from Table 2 that specific clinical features were not associated with any one type of bacterial species. Coagulase-negative staphylococci were the commonest single group of bacteria isolated. No bacteria were isolated from any specimens taken from asymptomatic patients. Mixed cultures did not occur.

Table 3 shows that for most bacterial species there was little advantage in incubating the cultures beyond $24 \mathrm{~h}$. However it was significant that $41 \cdot 7 \%$ of the coagulase-negative staphylococci (the commonest single species isolated) were only apparent after $72 \mathrm{~h}$. In only one case did the Gram film indicate the presence of bacteria (the patient with Streptococcus faecalis infection). It is significant that the fluid from this patient had the single greatest bacterial count as shown by the pour plate colony count. Since the bacterial counts were generally low (see Table 3 ) it seems the Gram film is an unsuitable means of

Table 1 Results of bacterial culture of 59 specimens of peritoneal dialysate in relation to white cell count and presenting symptoms

\begin{tabular}{|c|c|c|c|c|c|c|c|c|}
\hline \multirow{2}{*}{$\begin{array}{l}\text { Result of } \\
\text { culture }\end{array}$} & \multirow[t]{2}{*}{ Total } & \multicolumn{3}{|c|}{ White cell count $\times 10^{\circ} / l$} & \multicolumn{2}{|l|}{ Clinical features } & \multirow[t]{2}{*}{ Other* } & \multirow[t]{2}{*}{ Asymptomatic } \\
\hline & & $0-100$ & $100-500$ & $500+$ & $\begin{array}{l}\text { Peritonitis } \\
\text { (first specimen) }\end{array}$ & $\begin{array}{l}\text { Peritonitis } \\
\text { (later specimen) }\end{array}$ & & \\
\hline $\begin{array}{l}\text { Positive } \\
\text { Negative } \\
\text { Totals }\end{array}$ & $\begin{array}{l}22 \\
37 \\
59\end{array}$ & $\begin{array}{r}3 \\
20 \\
23\end{array}$ & $\begin{array}{r}5 \\
8 \\
13\end{array}$ & $\begin{array}{r}14 \\
9 \\
23\end{array}$ & $\begin{array}{r}11 \\
3 \\
14\end{array}$ & $\begin{array}{r}5 \\
11 \\
16\end{array}$ & $\begin{array}{r}6 \\
6 \\
12\end{array}$ & $\begin{array}{r}0 \\
17 \\
17\end{array}$ \\
\hline
\end{tabular}

*"Other" clinical features-see Table 2. 
Table 2 Bacterial species isolated in relation to presenting clinical features

\begin{tabular}{|c|c|c|c|c|c|c|c|c|}
\hline \multirow{2}{*}{$\begin{array}{l}\text { Presenting } \\
\text { symptoms }\end{array}$} & \multirow[t]{2}{*}{ No } & \multirow{2}{*}{$\begin{array}{l}\text { Staph } \\
\text { epidermidis }\end{array}$} & \multirow[t]{2}{*}{ Ecoli } & \multicolumn{5}{|c|}{ Bacteria isolated } \\
\hline & & & & Staph aureus & Diphtheroids & $A S B$ & $\begin{array}{l}\text { Strep } \\
\text { faecalis }\end{array}$ & None \\
\hline Peritonitis & 30 & 9 & 3 & 2 & 0) & 1 & 1 & 14 \\
\hline Leak round catheter & 4 & 1 & () & i & 0 & 0 & 0 & 2 \\
\hline Tube blockage & 2 & $i$ & 0 & () & 0 & 0 & 0 & 0 \\
\hline Sore around cuff & 1 & () & () & 1 & 0 & 0 & 0 & 0 \\
\hline Scrotal swelling & i & 0 & () & i) & $i$ & () & () & 0 \\
\hline Labial oedema & 1 & () & () & 0 & 0 & () & 0 & 1 \\
\hline Slow drainage & 1 & 0 & () & () & () & () & () & 1 \\
\hline Rigor at bag change & 1 & 0 & 0) & 0 & 0 & 0 & 0 & i \\
\hline Hypotensive collapse & 1 & 0 & () & 0 & 0 & 0 & 0 & $i$ \\
\hline Asvmptomatic & 17 & () & 0 & 0 & 0 & 0 & 0 & 17 \\
\hline Totals & 59 & 12 & 3 & 4 & 1 & 1 & 1 & 37 \\
\hline
\end{tabular}

ASB $=$ aerobic spore-bearing bacillus.

demonstrating bacterial presence in these types of specimen. Thirteen of the 22 positive cultures were detected both by direct plating and pour plate methods. Of the remaining nine positive cultures, seven were detected by the pour plate method only, whereas two were detected by direct plating only.

The API profiles of coagulase-negative staphylococci remained unaltered for isolates obtained during the same episode of peritonitis. However, the profiles of staphylococci from patient GQ, who had three separate episodes of peritonitis, were the same in the first and second episode but different in the third.

Sensitivity testing showed that all strains of staphylococci isolated in this investigation were sensitive to cephalosporins.

Fifteen specimens were tested by gas liquid chromatography. Cell counts in these specimens varied between $1 \times 10^{6} / 1$ to $1000 \times 10^{6} / 1$ and five were culture-positive. In no case were volatile fatty acids detected. The fluids were found to be deleterious to the column and this test was not carried out on the remaining 44 specimens.

Leishman staining revealed the presence of occasional basophils, eosinophils and large mononuclear cells, but the majority of cells in all specimens with high white cell counts were neutrophil polymorphs.

\section{Discussion}

The convenience of continuous ambulatory peritoneal dialysis is achieved at the expense of an increased risk of infection. If the patients are carefully chosen and instructed in the necessary techniques this risk is small. Nevertheless episodes with the clinical features of bacterial peritonitis do occur and are potentially serious. Although bacteria have not always been isolated by conventional methods of culture, the fact that the clinical symptoms resolve following antibacterial therapy suggests that they are probably bacterial in origin.

The present study has shown that the yield of bacteria from dialysate specimens can be increased by culturing large volumes of fluid. This was simply achieved by using a pour plate method, a third of the positive cultures being obtained by this means only.

The bacteria isolated during the present investigation proved to be, in the main, species which are normal inhabitants of the skin flora. This is

Table 3 Recovery of bacteria after various incubation periods and colony counts in relation to species isolated

\begin{tabular}{|c|c|c|c|c|c|c|c|}
\hline & $\begin{array}{l}\text { Staph } \\
\text { epidermis }\end{array}$ & Ecoli & $\begin{array}{l}\text { Staph } \\
\text { aureus }\end{array}$ & Diphtheroids & $A S B$ & $\begin{array}{l}\text { Strep } \\
\text { faecalis }\end{array}$ & Total \\
\hline $\begin{array}{r}\text { Growth at } 24 \mathrm{~h} \\
\text { at } 48 \mathrm{~h} \\
\text { at } 72 \mathrm{~h}\end{array}$ & $\begin{array}{l}6(2) \\
1(1) \\
5(3)\end{array}$ & $\begin{array}{l}2(2) \\
1 \\
0\end{array}$ & $\begin{array}{l}4(2) \\
0 \\
0\end{array}$ & $\begin{array}{l}0 \\
1 \\
0\end{array}$ & $\begin{array}{l}0 \\
1 \\
0\end{array}$ & $\begin{array}{l}1(1) \\
0 \\
0\end{array}$ & $\begin{array}{r}13(7) \\
4(1) \\
5(3)\end{array}$ \\
\hline Totals & $12(6)$ & $3(2)$ & $4(2)$ & 1 & 1 & $1(1)$ & $22(11)$ \\
\hline $\begin{array}{l}\text { Mean colony count } \\
\text { (pour plate) }\end{array}$ & 15() & 31 & 240 & 19 & 500 & $20(x)$ & 一 \\
\hline Range of colony counts & ${ }^{*}(0-12(x)$ & $3-70$ & $1-4(x)$ & 19 & 500 & 2000 & - \\
\hline
\end{tabular}

Numbers in parentheses refer to first specimens from episodes of peritonitis.

*In two cases the pour plate was negative but culture was obtained in other media.

ASB = aerobic spore-bearing bacillus. 
perhaps to be expected, since other sources of infection-for example, perforation of the gut, are uncommon. In these circumstances it is not always easy to conclude that the organisms isolated are the cause of infection and not just the result of skin contamination. However such organisms were not isolated from the asymptomatic patients and the fact that successive isolates of Staph epidermidis from the same patient proved to have a consistent biochemical profile, taken with the fact that the episodes resolved when treated with antibiotics to which the strains were sensitive, suggests that these organisms were truly the cause of infection. Recognition of this fact is important because it allows a basis for rational decision on antibacterial therapy before laboratory results are received.

On the basis of the present results it would appear that no laboratory finding is entirely satisfactory as a means of predicting the presence of bacterial infection. The Gram film will only reveal organisms if they are present in very large numbers, and in the absence of anaerobic infection gas liquid chromotography is of little value. White cell counts are of slightly more use since counts in excess of $500 \times 10^{6} / 1$ tended to be associated with bacterial infection. However a number of infections were associated with lower counts. It would therefore appear that at present antibiotic therapy should be initiated if the clinical symptoms suggest bacterial peritonitis, pending results of the bacteriological culture.

From this investigation it appears that a cephalosporin drug would be suitable cover for the majority of cases which are staphylococcal in origin. In view of the fact that some cases are caused by Gram-negative bacilli (which have a variable sensitivity to cephalosporins) one of the newer members of this group-for example, cefuroxime or cefotaxime would probably be the drug of choice. If there is any clinical suspicion of gut perforation, metronidazole should be included in the provisional therapy.

I wish to thank Dr DM Harris for his interest and help and Dr MM Platts for her permission to study her patients. Thanks are also due to Mrs E Haworth, $\mathrm{Mr}$ $\mathrm{R}$ Gregory and Dr C Nicholson for their help in collecting data.

\section{References}

' Popovich RP, Moncrief JW. Decherd JF. Bomar JB. Pyle WK. The definition of a novel portable/wearable equilibrium peritoneal dialysis technique, Abstracts; American Society for Artificial Internal Organs 1976:64.

2 Rubin J. Rogers WA. Taylor HM, et al. Peritonitis during continuous ambulatory peritoneal dialysis. Ann Intern Med 1980;92:7-13.

${ }^{3}$ Gokal R. McHugh M, Fryer R. Ward MK. Kerr DN. Continuous ambulatory peritoneal dialysis: one year's experience in a UK dialysis unit. Br Med J 1980;281:474-7.

+ Bint AJ, Gokal R, Patton KR. Sornes S, Ward MK. Peritonitis in continuous ambulatory peritoneal dialysis; laboratory and clinical studies with cefuroxime. Royal Society of Medicine International Congress and Symposium Series, 1980). No 387 173-7.

5 Popovich RP, Moncrief JW, Nolph KD, Ghods AJ. Twardowsk ZJ, Pyle WK. Continuous ambulatory peritoneal dialysis. Ann? Intern Med 1978;88:449-56.

Requests for reprints to: Dr PA Fenton, Department of Bacteriology, Hallamshire Hospital, Glossop Road. Sheffield S10 2JF, England. 